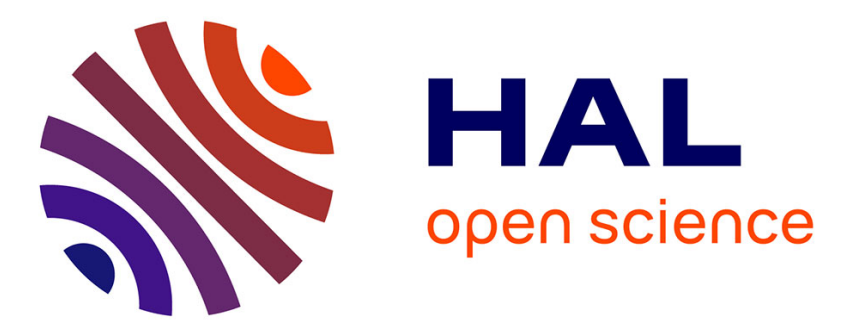

\title{
Socio-Technical Objects at the Crossroads Between 'Universal' Policy Models for Livestock Production Development, Local Practices and Dynamics of Change
}

Sergio Dario Magnani

\section{- To cite this version:}

Sergio Dario Magnani. Socio-Technical Objects at the Crossroads Between 'Universal' Policy Models for Livestock Production Development, Local Practices and Dynamics of Change. Nomadic Peoples, 2020, 24, pp.286 - 298. 10.3197/np.2020.240208 . hal-03547354

\author{
HAL Id: hal-03547354 \\ https://hal.science/hal-03547354
}

Submitted on 28 Jan 2022

HAL is a multi-disciplinary open access archive for the deposit and dissemination of scientific research documents, whether they are published or not. The documents may come from teaching and research institutions in France or abroad, or from public or private research centers.
L'archive ouverte pluridisciplinaire HAL, est destinée au dépôt et à la diffusion de documents scientifiques de niveau recherche, publiés ou non, émanant des établissements d'enseignement et de recherche français ou étrangers, des laboratoires publics ou privés. 


\title{
SOCIO-TECHNICAL OBJECTS AT THE CROSSROADS BETWEEN 'UNIVERSAL' POLICY MODELS FOR LIVESTOCK PRODUCTION DEVELOPMENT, LOCAL PRACTICES AND DYNAMICS OF CHANGE
}

\author{
Sergio Magnani
}

\section{Abstract}

\begin{abstract}
Relationships between public policy, resource management and the larger economic contexts remain poorly understood in the African drylands. A better understanding of changes in pastoral systems requires shifting the focus from a static and linear analysis to a dynamic one encompassing processes, relationships and contexts.

A three-year fieldwork research experience on three different case studies in Senegal has led to the identification of three material objects at the interface between pastoral systems and development interventions: cattle breeds, feeding and milk. Such objects are at the heart of pastoral systems, and are typically crucial to policymakers' attempts to intensify pastoral production.

By raising the example of cattle feeding in Northern Senegal, I suggest that a methodological and analytical framework focusing on the socio-political dimensions of technical objects can be useful to analyse the encounter between the linear and universal input/output rationality of livestock development models and those of pastoralists, based on the embeddedness of socio-political, economic and environmental variability.

Such an approach, I thus argue, can be used to deconstruct production models, highlighting the context of production and the modes of operation of the social actors. This could open up a space to describe social and technical change beyond abstract and 'universal' development models, and to promote more inclusive and empirically based policy-making.
\end{abstract}

KEYWORDS: Socio-technical objects, development models, pastoral practices, social change, Senegal

\section{Introduction}

Livestock production models since the colonial era fail to take account of the environmental, cultural and productive characteristics of African drylands. Based on an equilibrial understanding of drylands and on ill-adapted concepts focusing on the environmental impact of pastoralism (carrying capacity, overgrazing, 
etc.; see Lafitte 2020; Sayre 2008, 2017), livestock production models have promoted technical interventions to control the environment through, for example, hydro-agricultural systems for humid zones in drylands, pastoral water development, enclosures of pasturelands and the fragmentation of diverse and complementary ecological areas (Galvin et al. 2008, Davis 2016).

Detailed analyses of WoDaaBe pastoral systems in the Sahel (see Schareika 2003, Krätli and Schareika 2010), have shown that pastoralism can be understood as a system of production specialising in improving animal nutrition and herd performance, by exploiting the short-term effects of climatic variability on the nutritional value of vegetation (Krätli 2015). While these scientific advances now enjoy a growing formal recognition across Africa (see, for example, African Union 2010, Republic of Kenya 2012), they have had a limited impact in reshaping pastoral development models.

Two factors explain the persistence of the mainstream development models for livestock production. First, the institutional and political dynamics that reflect the interests of influential national and international actors in the development sphere (Davis 2016, Toulmin and Brock 2016) and second, the difficulty of reconstructing the conceptual and methodological foundations of pastoral development, which has long been rooted in the mainstream framework of animal science (Krätli 2008, 2016). This framework, wrongly considered as a universal reference (i.e. one that can be applied and replicated everywhere), follows a linear logic, whereby adding 'intensive' inputs (veterinary products, feed, water) is assumed to establish uniform and stable conditions which free livestock systems from environmental constraints and so maximise output (Griffon et al. 2015: 43). ${ }^{1}$

The problematic universality of the framework is reinforced by its role in international development. As with other standardised 'travelling models' (Olivier De Sardan 2019), the 'intensification' of livestock production is abstracted from contexts and arbitrarily recognised as a successful mode of production to be replicated elsewhere. The model is rooted in the industrial mode of animal production based on three major measures: first, to 'improve' the genetic potential of breeds specialised in a particular production; second, to maximise the use of feed in order to realise a target production potential reflecting the metabolic capacity of the animal in transforming inputs into outputs; third, to accentuate the commercial dimension of the desired production in order to cover costs and maximise profit. This mode of production depends on a highly artificialised socio-technical environment (e.g. genetic animal research, globalised feed production and farm machinery), relying on specific

1 Krätli et al. (2015) have shown the major methodological traps in applying this framework to pastoral systems in contexts of high variability (e.g unsuitable scales of observation, performance indicators abstracted from dynamics of resources, etc.). 
political and economic conditions (Micoud 2003) and understanding the environment as conceptually separable from society.

Development models based on linear understanding of how technical objects interact with pastoral production systems ignore the different processes of confrontation and negotiation which give specific existence and meanings to technical objects. In this way, such development models create 'black boxes' that become powerful political tools to naturalise and impose normative social and economic patterns of organisation (Akrich 1987). This is particularly problematic in arid environments, or those contexts characterised by high social, economic or political variability which necessitate constant negotiation between societies and their use of technical objects.

I thus argue that an analysis of livestock production which brings technical objects back within their contexts and takes into account their socio-political dimension can shed light on the social relationships and interactions that take place in specific places at given moments and thus inform more situated policymaking. In the following sections, I will present a methodological framework that mobilises socio-technical objects in order to study the implementation of an agri-business project for dairy development in northern Senegal and its implications for the practice of pastoralism in the region.

Using the three years of field research experience in Senegal, I illustrate how I used feed as an analytical socio-technical object to reveal how the dairy incentives have been opportunistically transformed to manage pastoral systems in a highly variable social, political and economic environment with constrained access to valuable resources.

I show that such a framework brings into focus different representations, meanings and objectives linked to pastoral production as well as the ways in which they overlap in the historical context under study. I will conclude by discussing the need to overcome black box representations of pastoral production.

\section{Socio-technical objects at the interface between dairy development models and pastoral realities in Northern Senegal}

In my doctoral research, ${ }^{2} \mathrm{I}$ analysed the techno-scientific ideology of dairy and pastoral development in Senegal. In order to question the conditions of existence of such ideologies, I studied the ways in which dairy development operations have been implemented in various pastoral systems in different

2 S. Magnani. 2016. Le lait local au Sénégal : intensifier pour développer? Dynamiques socio-techniques et anthropologie des pratiques. Marseille : EHESS. A twelve-month fieldwork project was conducted between 2011 and 2013. 
regions - that is, the spread of an industrial dairy model in the periphery of the capital Dakar; the creation of a dairy basin based on agriculture-livestock integration in the sub-humid region of Casamance; and the implementation of an intensification scheme to improve pastoral production in the semi-arid environment surrounding the Senegal River Valley.

The adjective 'socio-technical' refers to the overlapping social, political and environmental dimensions inherent to technical objects. Several authors mobilise this term to emphasise different aspects of the relationships between society and technology, which are of interest for the methodological considerations discussed in the article.

For example, Akrich (1987) uses the notion of 'socio-technical networks' to describe the set of actors and the space of relationships defined by the design and uses of technical objects (in her analysis, photovoltaic lighting kits, etc.). Akrich shows that technical objects act as mediators between the 'world' of the designers and that of the users. By studying the socio-technical network, the political content that designers inscribe in the object (pre-defined uses and users, norms, incentives, sanctions) and the forms that such objects take (which depend on the environment of different users) become explicit.

Casciarri (2013) mobilises the concept of 'socio-technical systems' to emphasise that the technical, social and political dimensions of systems of knowledge are inseparable, and that social and political immaterial elements are key to understanding entire systems, as she showed in a study of local institutions for pastoral water management in African drylands.

Finally, Darré $(1986,1996)$ uses the concept of 'actors' socio-technical position' to put into perspective the discourse, meaning and practices of French livestock farmers and of field agents from development institutions. With regard to the organisation of livestock systems and the relationships with the physical and economic environment, he shows that the techno-scientific knowledge of field agents and the practical knowledge of livestock farmers are both socially constructed. In contexts of structurally different representations of reality, gaps need to be made explicit in order to build cross-learning and common knowledge among the socio-professional groups in interaction (Compagnone et al. 2015).

Conventional models for livestock development often overlook the broad social, political and environmental dimensions of technical objects in order to build new configurations that fit the techno-political objectives of planned intervention (Magnani et al., 2019 a, b). By contrast, as these authors show and I argue, situating socio-technical objects as mobile objects at the interface between different forms of knowledge and practices highlights the power relationships underlying the interaction between local and external socio-technical systems and the resulting changes. Hence, in my own research, I referred to the 
concept of socio-technical objects as a common analytical grid for my analysis in the three different field sites mentioned above. I chose to concentrate on three socio-technical objects that are foundational in pastoral systems: cattle breeds, the feeding of cattle and milk.

- Cattle breeds represent both the product of pastoral systems and the key factor shaping their development. They play a central role in constructing collective identity in pastoral societies and shaping their relationships with the physical and socio-economic environment.

- The feeding of cattle reflects pastoralists' knowledge and access to resources and is at the heart of the tension between the mobility-based practices central to pastoral systems, and the sedentary technical models of intensification.

- Milk illustrates the complexity of relations between the economic, social and symbolic dimensions. Measures to commercialise milk can bring about significant change, as milk has multiple uses and meanings in the pastoral 'world', reflecting the social organisation of pastoral production and particularly the sexual division of labour.

In order to show how I operationalised the use of socio-technical objects during fieldwork I will focus on one of the three socio-technical objects, cattle feeding, and refer to my main field of study, a pastoral area surrounding the Senegal River Valley, around the city of Richard Toll.

\section{Context and methodological approach}

As I will explain, the historical influence of development policy clearly indicates how development interventions have transformed the practice of pastoralism around the valley. This is prerequisite for understanding the current evolutions of the socio-political dimensions of technical objects.

The Valley of the Senegal River has long been settled and is home to different populations including Toucouleurs, Fulani, Wolofs, Moors and Soninke. The region under study is located at the intersection between two main centres of settlement: Wolof in the delta of Senegal River and Fulani upstream (Boutillier et al. 1962: 15-21). Land use management was historically structured by two adjacent and heterogenous agro-ecological zones: the waalo, the riverbed and floodplain; and the jeeri, the drier area with sand dunes running parallel to the Valley. Until recently these two areas were used for agriculture and pastoralism in a complementary manner (Schmitz 1986). The waalo was organised to allow for different uses of the land throughout the season: fishing during flood periods, followed by flood-recession agriculture and then livestock farming to 
consume residues after the harvests of the dry season (Boutillier and Schmitz 1987). Fulani pastoralists practiced seasonal migrations between the waalo and the jeeri. The jeeri was exploited from the beginning of the rainy season until the ponds dried out. During the dry season, the pastoralists moved to the Valley to feed their herds on crop residue, manuring the fields and exchanging their produce with the farmers. This system allowed pastoralists to provide their herds with diversified nutrition throughout the year (Touré and Arpaillange 1986).

From the 1950s onwards, a vast programme of pastoral water development was implemented in the jeeri. The construction of boreholes favoured a partial sedentarisation of pastoralists on rainy-season rangelands (Barral 1982). From the 1970s onwards, these changes were amplified by interventions aimed at developing hydro-agriculture through the construction of a network of dams. ${ }^{3}$ With the Valley transformed into an exclusively agricultural area, pastoralists ceased migrating to the waalo and lost access to the diversity of resources that complemented the pastures in the jeeri. The development of irrigation in the area mainly benefited the Wolof farmers, who obtained rights to more irrigated land. The Fulani were progressively integrated in the schemes but extended families were forced to divide their time between agricultural and pastoral activities, a difficult exercise often resulting in the separation of family groups (Santoir 1983: 151-160).

These development interventions transformed the practice of pastoralism around the Valley. The majority of pastoralists settled in the jeeri, stopped farming and reorganised the pastoral activity in line with the market economy (Ancey et al. 2009). In parallel, agri-business irrigated agriculture is undergoing a dynamic expansion in the region (Koopman 2012, Soullier et al. 2016).

Within this context, my research objective was to understand the dynamics driven by an industrial dairy founded in 2006 that collected milk from several hundred mobile Fulani pastoralists in the drylands surrounding the Valley. Run as a social business, the dairy model provided pastoralists with feed inputs on credit (industrial feeds and agricultural residues from sugarcane agri-business) in order to settle the dairy cows in the dry season and so increase the volume of milk collected at a time when milk is scarce.

My methodological framework first identified the socio-technical network around the selected objects (breed, feed and milk). The network includes the coalition running the dairy industry (the Danone dairy group, the Senegalese enterprise, social business investment funds); their allies in international development (an international cooperation, a financial backer, an international non-governmental organisation and international research institutions); local

3 The Compagnie Sucrière Sénégalaise (CSS), the largest agro-industry in the country, was created in Richard Toll in 1970. 
partners (a Sugar Company, local authorities, livestock development and veterinary services); as well as Fulani pastoralists' extended families with different practices and attitudes towards dairy collection. During fieldwork, I 'moved back and forth' within this social network by collecting, observing and linking the discourses and practices of these different actors concerning breeds, cattle feeding and milk.

On the one hand, the use of socio-technical objects provided anchoring points to understand how coalitions were built and how heterogenous interests were aggregated through consensual representations of pastoral and territorial development and visions of change. On the other, it allowed me to bring to light the representations of pastoralists concerning their changing livelihood systems and pastoral practices with regard to access to resources, the demands and opportunities linked to the emergence of a new dairy market and the technical models proposed by development.

In order to illustrate the outcomes of the operationalisation of the methodological framework described above, in the following section I propose a synthesis of the analysis conducted around cattle feeding.

\section{Cattle feeding as analytical framework}

When discussing the services provided to pastoralists, the dairy and its partners focused on the innovative provision of feed on credit to encourage the Fulani pastoralists to settle dairy cows during the dry season and so limit the variations in milk collection throughout the year. Sugarcane residues and industrial feeds were intended as a balanced feed intake for individual dairy cows with limited mobility.

The feed provision model was based on two main assumptions:

1 - A direct correlation between feed provision and milk collection. The quantities of feeds provided annually to pastoralists were interpreted as an indicator of the positive impact of the project. According to this logic, the larger the volumes of feed, the stronger the pastoralists' commitment to the proposed development model and so the higher the quantity of milk collected.

2 - The Fulani pastoralists' willingness to intensify their production systems by settling dairy cows and to change their way of life in favour of sedentarisation.

Both assumptions proved misleading and are a result of lack of understanding of socio-technical objects in their specific contexts, relationships and cultural practices, particularly as concerns pastoral mobility. 
In order to understand how the dairy services were used by pastoralists over the period of study we first need to look more closely at changes in pastoral mobility. As mentioned, before the development of hydro-agriculture, pastoralists spent the dry season in the Valley, before moving with the first rains to the jeeri, where extended families split up. The oldest family members settled around the first ponds with children, dairy cows and calves and started sowing millet. The youngest shepherds moved south in groups to meet the monsoon front and then follow its progressive development northwards to come back to their starting point when the rainy season was uniformly established. This mobility, called polindaaji, ensured that mobile cows benefitted from nutritious young grass sprouts.

Since the exclusion from wet pasture in the Valley, mobility has been dictated by the progressive exhaustion of pastures around pastoral boreholes in the jeeri. The timing of these movements is unpredictable depending on the quality of the previous rainy season but mobility, always limited to the dry season, is often difficult. Progressively weakening cows have to walk for kilometres in the heat to find pockets of poor-quality dry grass far from water points. Polindaaji mobility has been shortened because pastoralists are in a hurry to return home to exploit pastures close to their camps before their neighbours do.

The centrality of feeds for pastoralists has to be understood in a context where environmental variability, once managed efficiently through mobility, has now become a constraint because of political changes in land and resource management. Cattle feeds mainly serve as a supplement to pastures during the dry season in an attempt to compensate for loss of access to the Valley. At the herd level, pastoralists safeguard the more fragile animals in the herds that cannot walk in search of pastures when conditions are harsh. Pastoralists I talked with generally described the benefits of animal feeds with expressions like 'give them the strength to hold on', 'avoid or treat diseases', 'prevent animals from falling to the ground'. No feeds are given in the wet season because green pastures are unanimously regarded as the 'complete feed' for cows, and not, as alleged by dairy collection staff, only a part of feed intake.

A heavy drought in 2012 provides a good example of how the pastoralists adapted the dairy feed services to their needs. Following an extremely poor rainy season throughout northern Senegal in 2011, pastoralists were exposed to a difficult choice: move south immediately after the end of the rains and endure a year-long mobility several hundred kilometres away, or stay and face the unpredictable evolution of pastures in the region. Most decided to stay. However, pastures quickly became rare as other pastoralists came from the eastern jeeri and Mauritania. Moving south was impossible because the intermediary region of Jolof also lacked pastures and access to boreholes was costly, with very high fees designed to discourage transhumant pastoralists. The only solution was to 
acquire as much feed as possible. Hence, the dairy feed service became a great opportunity to offload a part of the costs incurred. The dairy business's primary objective was to maintain the collection throughout the year to demonstrate the project's stability to partners, so it allowed pastoralist to delay their payments for feed. Fulani pastoralists seized the opportunity. Though part of the produced milk was collected by the dairy, pastoralists' goal was to maximise the reproductive capacity of the herds, namely the life of the calves. Finally, pastoralists' debt reached a record level and its recovery was progressively absorbed by the sale of milk during the following rainy seasons. ${ }^{4}$ The rationale of the dairy company on the provision of feeds proved to be wrong: the more feed requested by the pastoralists, the less milk collected by the dairy because the use of large quantities of feed was the sign of poor pasture conditions. Furthermore, the debt repayment was problematic for poor pastoralists because it absorbed all earnings from milk sales, earnings that belong to women and are used to meet basic needs.

Through the analytical lens of cattle feeding as a socio-technical object, forms of variability have been revealed, rather than masked, to the extent of turning development interventions to favour pastoralists, even when these were intended to have the opposite effect of constraining core pastoral practices such as mobility. The politics, economics and socio-cultural characteristics of the object show how development incentives to produce more milk by reducing pastoral mobility have in fact been transformed into opportunities to better manage pastoral systems in a highly variable environment with constrained access to valuable resources.

Another analytical example reinforces the above point. The staff of the dairy noted that in some cases pastoralists were agreeing to leave dairy cows with less mobile members of their extended families throughout the year. Once again this was interpreted as a sign of pastoralists' willingness to intensify their systems ('reducing the size of the herds', 'specialising in dairy production') and changing their way of life ('willingness to send children to school'). Fieldwork results showed quite a different reality. Splitting up the family and the herd during the more intense stages of mobility was a well-known practice with the double advantage of sparing the more fragile members of both the family and the herd from the rigours of the transhumance, thus increasing and facilitating the mobility of the rest of the herd. This strategy was already established among wealthy pastoralists who were able to look after the family in the camps in the jeeri while moving the rest of their herds away. The dairy

4 Selling milk during the rainy season is generally profitable because milk production does not require inputs and the season coincides with the calving period. As quantities of milk available often exceed the dairy collection capacity, the dairy prioritises the pastoralists who agree to sell in the dry season. 
intervention has allowed poorer pastoralists to become more mobile while ensuring that the family could be fed with the milk of the dairy cows that stayed with them and covering the costs of the required animal feed with milk sales during the rainy season through the credit system.

Again, the rationale of the dairy company on the provision of feed to reduce the mobility of pastoral families, in highly variable environments, proved to be wrong. The dairy's incentives to specialise and sedentarise were selectively transformed within the socio-technical environment of pastoralists, where the opportunities provided by the dairy were used to better exploit the socio-economic diversity and so increase their options in face of environmental, political and economic variability.

Finally, the analysis through socio-technical objects brings to light the interaction of two distinct socio-technical 'worlds'. On one side, that of dairy development where dairy cows are considered as individuals, feed as an intake and a complement of production, productive specialisation a goal and stability as a means to reach it. On the other, the socio-technical 'world' of pastoralists where the driving unit of the pastoral system is the herd, seen as whole, in relation to feeds as a supplement of pastures and in relation to mobility. This embeds a set of territorial resources at a larger scale, multifunctionality as a guarantee of autonomy and resilience, and variability as something to be balanced by the internal diversity and flexibility of pastoral systems.

\section{Conclusion}

In this paper we have seen how a methodological framework focusing on socio-technical objects is helpful to overcome linear and static analysis and representations of pastoral systems and patterns of change emerging from livestock development models and their underlying methodological infrastructure. Such a framework brings to light the social, political and environmental characteristics of the contexts in which interventions take place and that determine its specific trajectories, as well as the constant re-adaptation of local choices and practices in face of complex forms of variability which cannot be captured with linear analysis.

In the case under study it has proved to be useful to identify the socio-technical network acting on the selected objects in the framework of a dairy development project in a pastoral context. Looking at the objects as socio-technical allowed exploration of the characteristics of a territory reshaped by development intervention in which the practice of pastoralism has deeply changed over time under heavy constraints in the access to resources. A comparative analysis of the relationships, representations and practices of dairy development actors and Fulani 
pastoralists around socio-technical objects was central to grasping the processes of adaptation and compromises that informally took place despite the very different rationales at play. This highlights how pastoralists have incorporated the dairy development project as one element of variability in their socio-political and economic environment, which can also bring opportunities.

Finally, a methodological framework based on socio-technical objects makes explicit the discrepancies and gaps in actors' rationales and practices, which offers an opportunity to conceive contemporary patterns of change far from uniform representations of industrial (intensified) and pastoral conceptions of livestock keeping. This provides room to bring politics back into focus and so enlarge the range of possible futures for local production systems in the drylands.

\section{Bibliography}

African Union. 2010. Policy Framework for Pastoralism in Africa: Securing, Protecting and Improving the Lives, Livelihoods and Rights of Pastoralist Communities. Department of Rural Economy and Agriculture. African Union, Addis Ababa, Ethiopia.

Ancey, V., A. Ickowicz, C. Corniaux, C. Manoli and S. Magnani. 2009. 'Stratégies pastorales de sécurisation chez les Peuls du Ferlo (Sénégal)'. Journal des africanistes 78 (1-2): 105-119.

Akrich, M. 1987. 'Comment décrire les objets techniques?' Techniques et culture 9: 49-64. https://doi.org/10.4000/tc. 863

Barral, H. 1982. Le Ferlo des forages. Gestion actuelle et ancienne de l'espace pastoral. Dakar: ORSTOM.

Boutiller, J.L., P. Cantrelle, J. Causse, C. Laurent and T.H. Ndoye. 1962. La Moyenne Vallée du fleuve Sénégal. Paris: Presses Universitaires de France.

Boutiller, J.L. and J. Schmitz. 1987. 'Gestion traditionnelle des terres et transition vers l'irrigation. Le cas de la vallée du Sénégal'. Cahier des Sciences Humaines 23 (3-4): 533-554.

Casciarri, B. 2013. 'Systèmes sociotechniques, savoirs locaux et idéologies de l'intervention. Deux exemples de gestion de l'eau chez les pasteurs du Soudan et du Maroc'. Presses de Sciences Po-Autrepart 65 (2): 169-190. https://doi.org/10.3917/autr.065.0169

Compagnone, C., B. Hubert, J. Lasseur, R. Le Guen and A. Mathieu. 2015. 'Connaissances et systèmes de pensée des agriculteurs: L'actualité de l'approche de Jean-Pierre Darré'. Sens des pratiques et dynamique des collectifs en agriculture. L'actualité des travaux de Jean-Pierre Darré, Sept. 2015, Dijon, France. 10 p.

Darre, J.P. 1986. La parole et la technique : l'univers de la pensée des éleveurs du Ternois. Paris: Editions L'Harmattan. 
Darre, J.P. 1996. L'invention des pratiques dans l'agriculture : vulgarisation et production locale de connaissance. Paris: Editions Karthala.

Davis, D.K. 2016. The Arid Lands: History, Power, Knowledge. Boston: Massachusetts Institute of Technology. https://doi.org/10.7551/mitpress/10651.001.0001

Galvin, K.A., R.S. Reid, R.H. Behnke Jr. and N. Thompson Hobbs (eds). 2008. Fragmentation in Semi-Arid and Arid Landscapes: Consequences for Human and Natural Systems. Dordrecht: Springer, 2008.

Griffon, M., F. Jacquet, E. Lemaire et al. 2015. 'Emergence de l'agroécologie et perspectives pour le futur'. Cahiers de l'ANR $\mathbf{8}$.

Koopman, J. 2012. 'Lands grab, government, peasant and civil society activism in the Senegal River Valley'. Review of African Political Economy 39 (134): 655-664. https://doi.org/10.1080/03056244.2012.738797

Krätli, S. 2008. Time to outbreed animal science? A cattle-breeding system exploiting structural unpredictability: the Wodaabe herders in Niger. STEPS Working Paper 7, Brighton: STEPS Center.

Krätli, S. 2015. Valuing Variability: New Perspectives on Climate resilient Drylands

Development. Ed. By H. de Jode. IIED.

Krätli, S. 2016. 'Discontinuity in pastoral development: time to update the method'. Revue Scientifique et Technique de l'Office International des Epizooties 35 (2): 485-497. https://doi.org/10.20506/rst.35.2.2528

Krätli, S. and N. Schareika. 2010. 'Living off uncertainty: The intelligent animal production of dryland pastoralists'. European Journal of Development Research 22 (5): 605-622. https://doi.org/10.1057/ejdr.2010.41

Krätli, S., B. Kaufmann, H. Roba, P. Hiernaux, L. Wenjun, M. Easdale and C. Hülsebusch. 2015. A House Full of Trap Doors. Identifying Barriers to Resilient Drylands in the Toolbox of Pastoral Development. IIED, DITSL.

Magnani, S., V. Ancey and B. Hubert. 2019a. 'Dairy policy in Senegal: the need to overcome a technical mindset'. European Journal of Development Research 31 (5): $1227-1245$. https://doi.org/10.1057/s41287-019-00208-4

Magnani, S., V. Ancey and B. Hubert. 2019b. '(Dis)ordered intensification? Technopolitical models, resource access and pastoralist/agribusiness relations in the Middle Valley of the Senegal River'. Nomadic Peoples 23 (1): 5-27. https://doi.org/10.3197/np.2019.230102

Micoud, A. 2003. 'Ces bonnes vaches aux yeux si doux'. Communications, De Gruyter, pp. 217-237.

https://doi.org/10.3406/comm.2003.2137

Olivier De Sardan, J.P. 2019. Industrie du développement: les mésaventures des modèles voyageurs. AOC - Media, at https://aoc.media/analyse/2019/09/25/ industrie-du-developpement-les-mesaventures-des-modeles-voyageurs/ 
Republic of Kenya, Ministry of State for Development of Northern Kenya and Other Arid Lands. 2012. Releasing Our Full Potential. Sessional Paper n ${ }^{\circ}$ 8, on National Policy for the Sustainable Development of Northern Kenya and other Arid Lands. Nairobi.

Sayre, N.F. 2008. 'The genesis, history, and limits of carrying capacity'. Annals of the Association of American Geographers 98 (1): 120-134. https://doi.org/10.1080/00045600701734356

Sayre, N.F. 2017. The Politics of Scale: A History of Rangeland Science. Chicago: The University of Chicago Press. https://doi.org/10.7208/chicago/9780226083391.001.0001

Santoir, C. 1983. Raison pastorale et développement. Les problèmes des Peul sénégalais face aux aménagements. Paris: Travaux et Documents de l'ORSTOM.

Schareika, N. 2003. Know to Move, Move to Know. Ecological Knowledge and Herd Movement Strategies among the Wodaabe of Southern Niger. Rome: FAO.

Schmitz, J. 1986. 'L'état géomètre : les leydi des Peuls du Fuuta Tooro et du Maasina'. Cahiers d'Etudes Africaines 103 (103): 349-394. https://doi.org/10.3406/cea.1986.1707

Souiller, G., P. Moustier, A. Ba and J. Bourgoin. 2016. Les effets des agrobusiness sur les petits producteurs dans la vallée du fleuve Sénégal: résultats de trois études de cas. Montpellier: CIRAD.

Toulmin, C. and K. Brock. 2016. 'Desertification in the Sahel: Local practice meets global narrative'. In R.H. Behnke and M. Mortimore (eds), The End of Desertification? Disputing Environmental Change in the Drylands. Dordrecht: Springer. pp. 37-63. https://doi.org/10.1007/978-3-642-16014-1_2

Toure, O. and J. Arpaillange. 1986. Peul du Ferlo. Paris : L'Harmattan.

Sergio Dario Magnani holds a Ph.D. in Social Anthropology from the French School of Advanced Studies in the Social Sciences. His works focus on dynamics of social and economic change of pastoral societies, as driven by their relationships with development policy. He is an independent researcher in Anthropology and advisor on pastoral Development.

Email :semagnani@gmail.com 